\title{
PENGARUH MODEL PEMBELAJARAN INQUIRY BERBANTUAN MEDIA ANIMASI TERHADAP KOMPETENSI PENGETAHUAN IPA
}

\author{
Ayu Cintya Dewi ${ }^{1}$, Made Putra ${ }^{2}$, I Gst Agung Oka Negara ${ }^{3}$ \\ 1,2,3 Jurusan Pendidikan Guru Sekolah Dasar, FIP \\ Universitas Pendidikan Ganesha \\ Singaraja, Indonesia \\ e-mail: cintya.dewi@undiksha.ac.id ${ }^{1}$, madeputra@undiksha.ac.id ${ }^{2}$, \\ igustiagungoka.negara@undiksha.ac.id3
}

\begin{abstract}
Abstrak
Penelitian ini bertujuan untuk mengetahui perbedaan yang signifikan kompetensi pengetahuan IPA antara kelompok siswa yang dibelajarkan melalui model pembelajaran Inquiry berbantuan media animasi dengan kelompok siswa yang dibelajarkan melalui pembelajaran konvensional pada siswa kelas IV SD Gugus Dewi Sartika Tahun Ajaran 2017/2018. Jenis penelitian ini adalah eksperimen semu dengan rancangan non-equivalent control group design. Populasi penelitian ini adalah seluruh siswa kelas IV SD Gugus Dewi Sartika sebanyak 266 siswa. Sampel ditentukan dengan teknik random sampling sehingga diperoleh kelas IV SD Negeri 3 Pedungan sebagai kelompok eksperimen sebanyak 45 orang dan kelas IV B SD Negeri 13 Pedungan sebagai kelompok kontrol sebanyak 30 orang. Pengumpulan data dalam penelitian ini dilakukan dengan metode tes dan instrument yang digunakan berupa tes objektif pilihan ganda biasa. Data kompetensi pengetahuan dianalisis dengan uji-t polled varian. Hasil analisis menunjukkan bahwa terdapat perbedaan yang signifikan kompetensi pengetahuan IPA antara kelompok siswa yang dibelajarkan melalui model pembelajaran Inquiry berbantuan media animasi dengan kelompok siswa yang dibelajarkan melalui pembelajaran konvensional pada siswa kelas IV SD Gugus Dewi Sartika Tahun Ajaran 2017/2018. Dengan demikian dapat disimpulkan bahwa model pembelajaran Inquiry berbantuan media animasi berpengaruh terhadap kompetensi pengetahuan IPA siswa kelas IV SD Gugus Dewi Sartika Tahun Ajaran 2017/2018, dan model pembelajaran Inquiry berbantuan media animasi dapat digunakan dalam pembelajaran IPA sehingga tercipta pembelajaran yang bermakna.
\end{abstract}

Kata kunci: Inquiry, Animasi , kompetensi pengetahuan

\section{Abstract}

This study aimed at determining the significant effect of science knowledge competence between groups of students who are taught by using inquary learning model which assisted by animated media with groups of students who are taught through conventional learning in fourth grade students of SD Gugus Dewi Sartika academic year 2017/2018. This study was a quasi experimental research with non-equivalent control group design. The population of this study was all fourth grade students of SD Gugus Dewi Sartika which amounted to 266 students. The sample was determined by random sampling technique so that there would be fourth grade of SD Negeri 3 Pedungan as experiment group which amounted to 45 people and fouth grade B of SD Negeri 13 Pedungan as control group which amounted to 30 people. The data collection in this research was done by the test method and the instrument used in the form of ordinary double choice objective test. Data of knowledge competence was analyzed by $t$-test polled variance. The analysis result indicated that there was a significant effect of science knowledge competence between group of students which was taught by using inquary learning model which assisted by animated media with group of students that was taught by using conventional learning in fourth grade students of SD Gugus Dewi Sartika academic year 2017/2018. Thus, it can be concluded that Inquiry Learning Model which assisted by animated media have a significant effect on science knowledge competence of fourth grade students of SD Gugus Dewi Sartika academic year 2017/2018, and the Inquiry Learning Model which assisted by animated media can be used in studying science so as to create the kind of learning.

Keywords : Inquiry, Animation, Science Knowledge Competence 


\section{Pendahuluan}

Pendidikan merupakan salah satu bentuk perwujudan kebudayaan manusia yang dinamis dan sarat perkembangan. Oleh karena itu, perubahan atau perkembangan pendidikan bertujuan untuk mengembangkan sumber daya alam yang berkualitas sehingga tercapainya pendidikan yang bermutu bagi masyarakat. Seperti yang didefinisikan dalam Undang-undang No. 20 Tahun 2003, pendidikan adalah usaha sadar dan terencana untuk mewujudkan suasana belajar dan proses pembelajaran agar peserta didik secara aktif mengembangkan potensi dirinya untuk memiliki kekuatan spiritual keagamaan, pengendalian diri, kepribadian, kecerdasan, akhlak mulia, serta keterampilan yang diperlukan dirinya, masyarakat, bangsa dan negara. Penyelenggaraan pendidikan yang bermutu akan menghasilkan sumber daya manusia yang bermutu dan mempunyai daya saing. Sumber daya yang berkualitas akan menentukan mutu kehidupan pribadi, masyarakat, dan bangsa dalam rangka mengantisipasi, mengatasi persoalan-persoalan, dan tantangan-tantangan yang terjadi dalam masyarakat pada masa kini dan masa depan. Salah satu upaya yang ditempuh oleh pemerintah untuk meningkatkan kualitas mutu pendidikan adalah melalui pengembangan kurikulum.

Kurikulum yang diterapkan saat ini adalah kurikulum 2013. Kurikulum 2013 menekankan pada pentingnya pembentukan karakter siswa di sekolah, terutama pada pendidikan dasar. Standar kompentensi lulusan yang dirumuskan dalam kurikulum 2013 secara umum yang terkait dengan sikap perilaku adalah pribadi yang beriman, berakhlak mulia, percaya diri dan bertanggung jawab dalam berinteraksi secara efektif dengan lingkungan sosial, alam sekitar serta dunia dan peradabannya. Pada penerapan kurikulum 2013 pada tingkat SD menggunakan tematik integratif, yaitu mengaitkan beberapa muatan mata pelajaran ke dalam sebuah tema. Pembelajaran tematik integratif tersebut dalam prosesnya menerapkan pendekatan saintifik.

Dalam proses pembelajaran di sekolah, salah satu pembelajaran yang diterapkan di sekolah dasar adalah pembelajaran IPA. IPA merupakan salah satu mata pelajaran pokok dalam kurikulum pembelajaran saat ini. Dahulu, saat ini dan saat yang akan datang IPA atau IImu Pengetahuan Alam memegang peran yang sangat penting dan alam kehidupan manusia. Hal ini disebabkan karena kehidupan kita sangat tergantung dari alam, zat terkandung di alam. IPA membahas tentang gejala-gejala alam yang disusun secara sistematis yang didasarkan pada hasil percobaan dan pengamatan yang dilakukan oleh manusia. Proses pembelajaran IPA yang bermakna dan menarik diharapkan mampu memotivasi siswa untuk meningkatkan kualitas pendidikan di Indonesia sehingga penyesuaian materi IPA yang akan diajarkan dengan penataan lingkungan belajar atau sistem sosial mampu mengoptimalkan keseluruhan komponen yang dimiliki peserta didik untuk mencapai kompetensi yang diharapkan. Putra (2017: Vol 5) menyatakan, "pembelajaran IPA di sekolah dasar sebaiknya memberikan kebebasan siswa untuk membuat atau menafsirkan suatu hal dalam kegiatan pembelajarannya untuk merancang dan menemukan sesuatu secara mandiri".

Setiap guru pasti mengharapkan materi yang telah disapaikan dapat diterima dan diterapkan oleh peserta didiknya. Berdasarkan hasil observasi dan wawancara dengan guru wali kelas IV SD Gugus Dewi Sartika khususnya tentang kompetensi pengetahuan IPA. Berdasarkan informasi yang didapat dikatakan bahwa pembelajaran di kelas belum terpusat pada siswa, siswa masih kurang percaya diri untuk menyampaikan pendapatnya, serta guru kurang mendesain model dan media pembelajaran yang inovatif sehingga siswa lebih aktif di dalam kelas. Salah satu upaya untuk mengatasi masalah tersebut adalah dengan menggunakan model pembelajaran Inquiry.

Inquiry merupakan salah satu model pembelajaran yang cocok digunakan dalam pemebajaran IPA karena menekankan pada peserta didik untuk mencari atau memahami informasi. Tabany (2014:79) menyatakan, "model pemebelajaran inquiry dirancang untuk mengajak siswa secara langsung ke dalam proses ilmiah ke dalam waktu yang relatif singkat". Sasaran utama kegiatan pembelajaran inquiry yaitu keterlibatan siswa secara 
maksimal dalam proses kegiatan belajar, keterarahan kegiatan secara logi dan sistematis pada tujuan pembelajaran, dan mengembangkan sikap percaya diri tentang apa yang ditemukan dalam proses inquiry. Model pembelajaran inquiry tidak saja meningkatkan pemahaman siswa terhadap konsep-konsep dalam IPA saja, melainkan juga membentuk keilmiahan pada diri siswa. Susanto (2013:174) menyatakan, "inquiry merupakan tingkah laku yang terlibat dalam usaha manusia untuk menjelaskan secara rasional fenomenafenomena rasa ingin tahu". Dengan kata lain, inquiry berkaitan dengan aktivitas dan keterampilan aktif yang fokus pada pencaraian pengetahuan atau pemahaman untuk memuaskan rasa ingin tahu.

Selain memperhatikan variasi model pembelajaran, pelaksanaan pembelajaran dikelas perlu didesain secara kreatif dan inovatif dengan memperhatikan media yang akan digunakan agar sesuai terhadap karakteristik peserta didik. Model pembelajaran inquiry jika dipadukan dengan media animasi dapat membuat siswa lebih aktif dan pembelajaran di kelas menjadi lebih bermakna. Suryantara (2014:Vol 2) menyatakan, "media gambar animasi merupakan suatu tampilan yang menggabungkan antara media teks, grafik dan suara dalam suatu aktivitas penggerakan". Kelebihan menggunakan media animasi yaitu animasi memiliki kemampuan untuk dapat menjelaskan sesuatu yang rumit hanya dengan gambar atau katakata saja. Dengan kemampuan ini maka animasi dapat digunakan untuk menjelaskan suatu materi yang secara nyata tidak dapat terlihat oleh mata, dengan cara melakukan visualisasi maka materi yang dijelaskan dapat tergambarkan. Media animasi dapat memberikan daya tarik atau memunculkan fokus baru terhadap sesuatu yang perlu dibantu sehingga dapat menarik perhatian pesrta didik untuk lebih bersemangat dalam mengikuti proses belajar mengajar di dalam kelas.

Berdasarkan uraian tersebut, maka dilakukan sebuah penelitian dengan judul "Pengaruh Model Pembelajaran Inquiry Bebantuan Media Animasi Terhadap Kompetensi Pengetahuan IPA Siswa Kelas IV SD Gugus Dewi Sartika Tahun Ajaran 2017/2018".

\section{Metode}

Penelitian ini dilaksanakan pada semester genap tahun ajaran 2017/2018 di SD Gugus Dewi Sartika yang bertujuan untuk mengetahui pengaruh model pembelajaran Inquiry berbantuan media animasi dengan siswa yang diberikan perlakuan model pembelajaran konvensional terhadap kompetensi pengetahuan IPA siswa. Jenis penelitian ini adalah eksperimen semu (Quasi Experiment), rancangan penelitian yang digunakan adalah Nonequivalent Control Group Design. Dalam desain ini, ada dua kelompok subjek yakni satu kelompok eksperimen dan satu kelompok sebagai kelompok kontrol. Kelompok eksperimen mendapat perlakuan khusus dengan menerapkan model pembelajaran inquiry berbantuan media animasi sedangkan untuk kelompok kontrol diterapkan pembelajaran konvensional. Kedua kelompok memperoleh prestest dan posttest.

Populasi adalah keseluruhan objek atau subjek yang memiliki kualitas dan karakteristik tertentu yang diteliti dan dipelajari untuk dapat menarik suatu kesimpulan. Populasi penelitian ini adalah seluruh siswa Kelas IV (empat) SD Gugus Dewi Sartika tahun ajaran 2017/2018, yang terdiri dari 7 kelas dalam 4 sekolah dasar. Jumlah populasi adalah 266 orang. Penentuan sampel menggunakan teknik random sampling yang dirandom kelasnya, sehingga setiap kelas mendapatkan peluang yang sama untuk menjadi sampel penelitian. Dengan demikian, dalam penelitian ini setiap anggota populasi yang ada di kelas IV SD Gugus Dewi Sartika memperoleh hak yang sama dan mendapat kesempatan dipilih menjadi sampel. Sampel yang digunakan dalam penelitian ini yaitu kelas IVB SDN 13 Pedungan dan kelas IV SDN 3 Pedungan. Untuk menentukan kelompok eksperimen dan kelompok kontrol sampel diuji terlebih dahulu kesetaraannya. Pengujian statistik kesetaraan sampel menyatakan kedua sampel setara dengan perolehan $t_{\text {hitung }}=1,043<t_{\text {tabel }}=2,000$. Selanjutnya dilakukan pengundian untuk menentukan kelompok eksperimen dan kelompok kontrol. Berdasarkan hasil random, diperoleh dua sekolah dasar sebagai sampel yaitu kelas 
IV SDN 3 Pedungan sebagai kelas eksperimen dan kelas IVB SDN 13 Pedungan sebagai kelas kontrol.

Metode pengumpulan data yang digunakan dalam penelitian ini adalah metode tes, dengan instrument berupa tes kompetensi pengetahuan IPA adalah tes objektif dalam bentuk pilihan ganda. Kemudian data dianalisis secara deskriptif, yaitu merupakan analisis yang dipakai untuk menganalisis data dengan mendeskripsikan atau menggambarkan datadata yang sudah dikumpul. Jika data yang diperoleh sudah memenuhi prasyarat uji normalitas dan homogenitas maka analisis yang digunakan adalah statistik parametrik. Analisis statistik yang digunakan untuk menguji hipotesis penelitian ini adalah uji beda mean (uji t). Uji Hipotesis menggunakan uji-t dengan rumus polled varians.

\section{Hasil dan Pembahasan}

Deskripsi data dalam penelitian ini memaparkan rata-rata (mean), standar deviasi dan varians kompetensi pengetahuan IPA pada kelompok eksperimen dan kelompok kontrol. Berdasarkan hasil perhitungan diperoleh nilai rata-rata kompetensi pengetahuan IPA, pada kelompok eksperimen yang dibelajarkan dengan model pembelajaran inquiry berbantuan media animasi adalah 86,07 dengan varians 50,15 dan standar deviasi 7,08. Berdasarkan hasil analisis statistik deskriptif kompetensi pengetahuan IPA siswa kelompok eksperimen diperoleh nilai rata-rata, $\bar{X}=86,07$ dan rata-rata persentase kompetensi pengetahuan IPA siswa kelompok eksperimen, $\mathrm{M} \%=86,07$. Rata-rata persentase kompetensi pengetahuan IPA tersebut kemudian dikonsultasikan dengan tabel konversi PAP Skala Lima dan berada pada kategori tinggi.

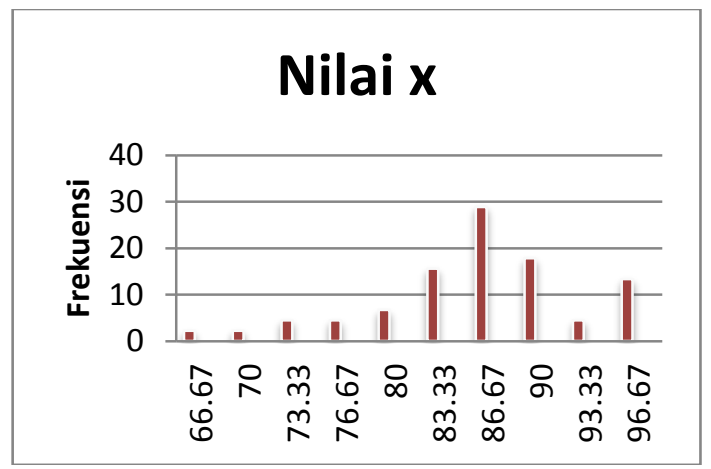

Gambar 1. Distribusi Frekuensi Kompetensi Pengetahuan IPA Kelompok Eksperimen dalam Diagram Batang

Sedangkan pada kelompok kontrol yang dibelajarkan melalui pembelajaran konvensional adalah 76,56 dengan varians 83,13 dan standar deviasi 9,12. Berdasarkan hasil analisis statistik deskriptif kompetensi pengetahuan IPA siswa kelompok kontrol diperoleh nilai rata-rata, $\bar{X}=76,56$ dan rata-rata persentase kompetensi pengetahuan IPA siswa kelompok eksperimen, $\mathrm{M} \%=76,56$. Rata-rata persentase kompetensi pengetahuan IPA tersebut kemudian dikonsultasikan dengan tabel konversi PAP Skala Lima dan berada pada kategori sedang. 


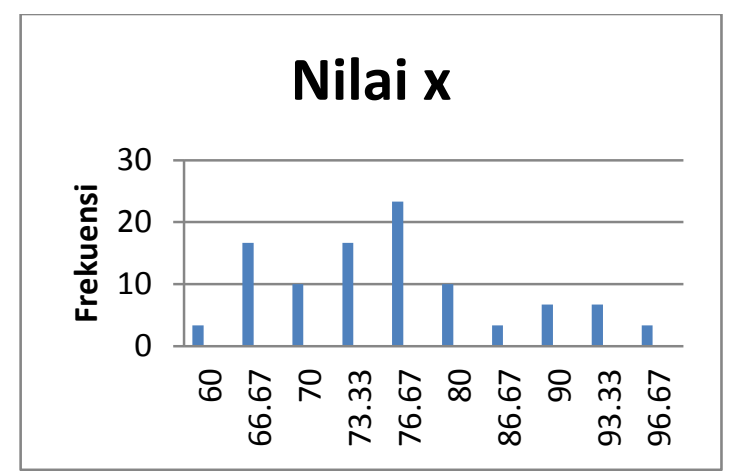

Gambar 2. Distribusi Frekuensi Kompetensi Pengetahuan IPA Kelompok Kontrol dalam Diagram Batang

Dari data tersebut diketahui bahwa nilai rata-rata yang diperoleh siswa kelompok eksperimen yang dibelajarakan melalui model pembelajaran inquiry berbantuan media animasi lebih tinggi dari nilai rata-rata yang diperoleh siswa kelompok kontrol yang dibelajarakan melalui pembelajaran konvensional. Uji prasyarat dilakukan terlebih dahulu sebelum uji hipotesis menggunakan uji-t. Uji prasyarat tersebut meliputi uji normalitas dan uji homogenitas varians.

Uji normalitas dilakukan untuk mengetahui sebaran frekuensi skor, untuk menguji data kompetensi pengetahuan IPA kelompok eksperimen dan kontrol. Uji normalitas data dilakukan pada kelompok eksperimen yang mengikuti pembelajaran menggunakan model pembelajaran inquiry berbantuan media animasi dan kelompok kontrol yang mengikuti pembelajaran konvensional. Dalam uji normalitas digunakan analisis Chi-Kuadrat $\left(x^{2}\right)$ dengan taraf signifikan $5 \%$ dan derajat kebebasan $(\mathrm{dk})=\mathrm{k}-1$. Nilai $X_{\text {tabel }}^{2}$ pada taraf signifikansi $5 \%(\alpha=0,95)$ dan derajat kebebasan $(\mathrm{db})=5$ diperoleh $X_{\text {tabel }}^{2}=11,070$.

Berdasarkan hasil uji analisis kelompok eksperimen diperoleh $X_{\text {hitung }}^{2}=7,50$. Karena $X_{\text {hitung }}^{2}<X_{\text {tabel }}^{2}$ maka data berdistribusi normal. Ini berarti sebaran data kelompok eksperimen berdistribusi normal. Sedangkan hasil uji analisis kelompok kontrol diperoleh $X_{\text {hitung }}^{2}=2,27 X_{\text {hitung }}^{2}<X_{\text {tabel }}^{2}$ maka data berdistribusi normal.. Ini berarti sebaran data kelompok kontrol berdistribusi normal.

Selanjutnya dilakukan uji homogenitas varians kelompok eksperimen yang mengikuti pembelajaran menggunakan model pembelajaran inquiry berbantuan media animasi dan kelompok kontrol yang mengikuti pembelajaran konvensional menggunakan uji $\mathrm{F}$ diperoleh $\mathrm{F}_{\text {hitung }}=1,66$ dengan derajat kebebasan pembilang (dk pembilang) $=45-1=44$ dan derajat kebebasan penyebut (dk penyebut) $=30-1=29$ pada taraf signifikansi $5 \%$. Berdasarkan tabel nilai-nilai distribusi $F$ diperoleh sebesar $F_{\text {tabel }}$ 1,79. Berdasarkan hasil penghitungan diperoleh harga $F_{\text {hitung }}<\mathrm{F}_{\text {tabel }}(1,66<1,79)$ maka $H_{0}$ diterima. Ini berarti varians data kompetensi pengetahuan IPA antara kelompok eksperimen dan kelompok kontrol adalah homogen.

Berdasarkan hasil uji prasyarat yang terdiri dari uji normalitas dan uji homogenitas varians, disimpulkan bahwa data kedua kelompok sampel ialah berdistribusi normal dan memiliki varians yang homogen. Karena data yang diperoleh telah memenuhi prasyarat, uji hipotesis dilakukan dengan analisis uji-t. Adapun Kriteria pengujian yaitu $\mathrm{H}_{0}$ ditolak dan $\mathrm{H}_{\mathrm{a}}$ diterima jika harga $t_{\text {hitung }}>t_{\text {tabel }}$ sedangkan $\mathrm{H}_{0}$ diterima dan $\mathrm{H}_{\mathrm{a}}$ ditolak jika harga $t_{\text {hitung }} \leq \mathrm{t}_{\text {tabel }}$. Harga $t_{\text {tabel }}$ didapatkan dari tabel distribusi $t$ pada taraf signifikan $5 \%$ dengan derajat kebebasan $\mathrm{dk}=\mathrm{n}_{1}+\mathrm{n}_{2}-2$. Rekapitulasi hasil analisis uji-t kelompok sampel penelitian ini disajikan dalam tabel 1 berikut ini. 
Tabel 1. Rekapitulasi Analisis Uji-t

\begin{tabular}{|c|c|c|c|c|c|c|c|c|}
\hline No. & Sampel & $\mathrm{N}$ & Dk & $\bar{X}$ & S2 & $t_{\text {hitung }}$ & $t_{\text {tabel }}$ & Status \\
\hline 1 & $\begin{array}{l}\text { Kelompok } \\
\text { Eksperimen }\end{array}$ & 45 & \multirow{2}{*}{73} & 86,07 & 50,15 & \multirow{2}{*}{4,876} & \multirow{2}{*}{2,000} & \multirow[t]{2}{*}{$\begin{array}{c}t_{\text {hitung }}>t_{\text {tabe }} \\
\mathrm{H}_{0} \text { ditolak }\end{array}$} \\
\hline 2 & $\begin{array}{l}\text { Kelompok } \\
\text { Kontrol }\end{array}$ & 30 & & 76,56 & 76,56 & & & \\
\hline
\end{tabular}

Berdasarkan hasil perhitungan uji-t, diperoleh $t_{\text {hitung }}=4,876$ dan untuk taraf signifikansi $5 \%$ dengan $\mathrm{dk}=((45+30)-2)=73$ diperoleh $t_{\text {tabel }}=2,000$. Dengan demikian, nilai $t_{\text {hitung }}>t_{\text {tabel }}$ yakni 4,876 > 2,000 sehingga Ho ditolak. Hal ini menunjukkan bahwa terdapat perbedaan yang signifikan kompetensi pengetahuan IPA antara kelompok siswa yang dibelajarkan melalui model pembelajaran Inquiry berbantuan media animasi dengan kelompok siswa yang dibelajarkan melalui pembelajaran konvensional pada Kelas IV SD Gugus Dewi Sartika tahun ajaran 2017/2018.

Berdasarkan analisis data, diperoleh nilai rata-rata kompetensi pengetahuan IPA pada kelompok eksperimen yaitu 86,07 dan kelompok kontrol yaitu 76,56. Hal ini menunjukkan bahwa nilai rata-rata kompetensi pengetahuan IPA kelompok eksperimen lebih tinggi dibandingkan dengan nilai rata-rata kompetensi pengetahuan IPA kelompok kontrol. Dari hasil perhitungan diketahui bahwa sebaran data kompetensi pengetahuan IPA kedua kelompok berdistribusi normal dan memiliki varian yang homogen. Dari hasil uji hipotesis diperoleh $t_{\text {hitung }}=4,876$ sedangkan pada taraf signifikansi $5 \%$ dan $\mathrm{dk}=73$ diperoleh nilai $\mathrm{t}_{\text {tabel }}$ $=2,000$ sehingga $t_{\text {hitung }}>t_{\text {tabel }}$. Dengan demikian Ho ditolak. Hal ini berarti terdapat perbedaan yang signifikan kompetensi pengetahuan IPA antara kelompok siswa yang dibelajarkan melalui model pembelajaran Inquiry berbantuan media animasi dengan kelompok siswa yang dibelajarkan melalui pembelajaran konvensional pada Kelas IV SD Gugus Dewi Sartika tahun ajaran 2017/2018.

Berdasarkan hasil temuan tersebut, dapat dinyatakan kedua kelompok sampel penelitian yang memiliki kemampuan setara, setelah diberikan perlakuan berupa pembelajaran dengan menggunakan model pembelajaran inquiry berbantuan media animasi dan mengikuti pembelajaran menggunakan pembelajaran konvensional diperoleh kompetensi pengetahuan IPA yang berbeda. Perbedaan yang signifikan kompetensi pengetahuan IPA disebabkan oleh perlakuan yang diberikan pada kedua kelompok sampel.

Pada kelompok eksperimen, kegiatan pembelajaran dibelajarkan menggunakan model pembelajaran Inquiry berbantuan media Animasi. Model pembelajaran inquiry merupakan sebuah model yang dalam kegiatan pembelajaran yang melibatkan secara maksimal seluruh kemampuan siswa untuk mencari dan menyelidiki sesuatu secara sistematis, kritis, dan logis sehingga mereka dapat merumuskan sendiri penemuannya dengan penuh rasa percaya diri. Dan media animasi merupakan suatu tampilan yang menggabungkan antara media teks, grafik dan suara dalam suatu aktivitas penggerakan. Pergerakan gambar itu dibentuk dengan menampilkan urutan gambar yang berubah sedikit demi sedikit pada kecepatan yang tinggi, sehingga menghasilkan objek gambar statik yang dapat bergerak seperti hidup. Model pembelajaran inquiry berbantuan media animasi merupakan model pembelajaran yang sangat cocok digunakan dalam proses belajar mengajar dikelas. Dengan menggunakan model pembelajaran inquiry yang menekankan pada aktivitas siswa untuk mencari dan menemukan sendiri penemuannya serta di bantu dengan media animasi yang dapat menumbuhkan rasa ingin tahu siswa dan memberikan daya tarik atau memunculkan fokus baru terhadap sesuatu yang perlu dibantu sehingga dapat menarik perhatian siswa untuk lebih bersemangat dalam mengikuti proses belajar mengajar di dalam kelas. Dengan cara melibatkan siswa dalam kegiatan pembelajaran, memilih media pembelajaran yang tepat, serta menyampaikan pembelajaran dengan menyenangkan akan menjadikan kegiatan pembelajaran di kelas menggembirakan. Selain itu dengan memberikan motivasi kepada siswa diharapkan dapat meningkatkan kompetensi IPA siswa dengan pemberian reward, baik berupa tepuk tangan, bintang maupun stiker dan memberikan motivasi bagi anakyang 
belum bisa menjawab. Dengan demikian siswa akan merasa pembelajaran yang didapatkan menyenangkan, bermanfaat dan bermakna sehingga materi pembelajaran IPA akan mudah dipahami oleh siswa, dan siswa mampu menerapkan dalam kehidupan sehari-hari.

Berbeda dengan kelompok kontrol yang diberikan perlakuan dengan menggunakan pembelajaran konvensional. Pembelajaran konvensional merupakan suatu pembelajaran yang biasa digunakan oleh guru dalam melaksanakan proses pembelajaran sehari-hari dan sifatnya masih sangat umum. Pembelajaran konvensional lebih menekankan pada pemberian ceramah, tanya jawab, dan pemberian tugas atau PR. Sistem pengajaran yang demikian ini menyebabkan siswa tidak berpartisipasi aktif dalam mengikuti pembelajaran, sehingga dikhawatirkan siswa tidak dapat meningkatkan pengembangan kemampuannya. Hal ini menunjukan bahwa guru adalah sumber informasi. Hal tersebut menyebabkan siswa merasa kesulitan dalam memahami materi IPA.

Dengan demikian, model pembelajaran inquiry berbantuan media animasi dapat direkomendasikan dalam membelajarkan siswa khususnya pada kegiatan pembelajaran yang berisi muatan materi IPA. Karena model pembelajaran inquiry yang menekankan pada aktivitas siswa untuk mencari dan menemukan sendiri penemuannya serta di bantu dengan media animasi yang dapat menumbuhkan rasa ingin tahu siswa dan memberikan daya tarik atau memunculkan fokus baru terhadap sesuatu yang perlu dibantu sehingga dapat menarik perhatian siswa untuk lebih bersemangat dalam mengikuti proses belajar mengajar di dalam kelas. Hal ini dapat membuat siswa memiliki pemikiran yang terbuka, imajinatif, dan inspirasi dalam mengembangkan pengetahuan siswa.

Hasil penelitian ini memperkuat penelitian yang dilakukan oleh Putra (2017) menyatakan, terdapat perbedaan yang signifikan hasil belajar IPA antara kelompok siswa yang dibelajarkan dengan model pembelajaran Inkuiri Terbimbing berbantuan Peta Pikiran dan kelompok siswa yang tidak dibelajarkan dengan menggunakan model pembelajaran Inkuiri Terbimbing berbantuan Peta Pikiran dan penelitian yang dilakukan oleh Suryantara (2014) menyatakan, terdapat perbedaan yang signifikan pada hasil belajar IPA antara kelompok siswa yang dibelajarkan dengan model pembelajaran scramble berbantuan media gambar animasi dengan kelompok siswa yang mengikuti model pembelajaran konvensional.

\section{Simpulan dan Saran}

Berdasarkan hasil analisis data post test nilai rata-rata kompetensi pengetahuan IPA kelompok eksperimen, setelah dibelajarkan menggunakan model pembelajaran inquiry berbantuan media animasi yaitu $\bar{X}=86,07$ dan hasil perhitungan dengan membandingkan $\mathrm{M}(\%)$ ke dalam PAP skala lima yang memperoleh hasil $86,07 \%$ yang masuk pada kategori tinggi. Berdasarkan hasil analisis data post test nilai rata-rata kompetensi pengetahuan IPA kelompok control, setelah dibelajarkan menggunakan pembelajaran konvensional yaitu $\bar{X}=$ 76,56 dan hasil perhitungan dengan membandingkan $\mathrm{M}(\%)$ ke dalam PAP skala lima yang memperoleh hasil $76,56 \%$ yang masuk pada kategori sedang.

Hasil analisis data post test menunjukkan bahwa rerata kompetensi pengetahuan IPA kelompok eksperimen lebih tinggi daripada rerata kelompok kontrol $(86,07>76,56)$. Berdasarkan hasil analisis uji-t diperoleh $t_{\text {hitung }}$ sebesar 4,876 dan ttabel dengan $\mathrm{dk}=45+$ $30-2=73$ pada taraf signifikansi $5 \%$ adalah 2,000 karena $t_{\text {hitung }}>t_{\text {tabel }}(4,876>2,000)$, maka $\mathrm{HO}$ ditolak. Hal ini membuktikan bahwa terdapat perbedaan yang signifikan kompetensi pengetahuan IPA antara siswa yang dibelajarkan melalui model pembelajaran inquiry berbantuan media animasi dengan siswa yang dibelajarkan melalui pembelajaran konvensional.

Jadi dapat disimpulkan bahwa penerapan model pembelajaran inquiry berbantuan media animasi berpengaruh terhadap kompetensi pengetahuan IPA siswa kelas IV SDN Gugus Dewi Sartika Denpasar Selatan Tahun Ajaran 2017/2018.

Berdasarkan hasil penelitian yang diperoleh, maka saran yang dapat disampaikan adalah sebagai berikut.

a) Kepada Guru 
Berdasarkan hasil penelitian ini, guru hendaknya dapat menambah wawasan mengenai inovasi pembelajaran sehingga mampu menerapkan atau mengembangkan pembelajaran di kelas secara lebih kreatif dan inovatif seperti menerapkan pendekatan saintifik dengan lebih optimal dan divariasikan dengan model pembelajaran inquiry berbantuan media animasi agar dapat memberikan dampak positif terhadap kompetensi siswa khusunya dalam pembelajaran IPA

b) Kepada Kepala Sekolah

Hasil penelitian ini dapat menjadi pedoman kepala sekolah untuk mengarahkan guru dalam merancang pembelajaran yang dapat meningkatkan antusias dan semangat siswa dalam mengikuti pembelajaran serta kepala sekolah dapat membantu untuk memfasilitasi terlaksananya model pembelajaran inquiry berbantuan media animasi guna mengoptimalkan kompetensi siswa khusunya dalam pembelajaran IPA sehingga mutu sekolah menjadi meningkat.

c) Kepada Peneliti Lain

Kepada peneliti lain hendaknya hasil penelitian ini dapat dijadikan kajian penelitian relevan serta peneliti lain dapat melakukan penelitian lebih lanjut dengan menggunakan model pembelajaran inquiry berbantuan media animasi, atau dapat pula dilakukan penelitian lebih lanjut pada sumber data atau sampel yang berbeda khususnya pada muatan materi IPA sehingga proses pembelajaran IPA dapat berlangsung optimal dan memberikan dampak positif bagi kompetensi pengetahuan IPA siswa.

\section{Daftar Pustaka}

Agung, A.A.G. 2011. Pengantar Evaluasi Pendidikan. Singaraja: Universitas Pendidikan Ganesha.

Agung, A.A.G. 2014. Metodelogi Pendidikan. Yogyakarta: Aditya Media Publishing.

Agung, A.A.G. 2016. Statistika Dasar untuk Pendidikan. Yogyakarta: Deepublish.

Arikunto, Suharsimi. 2015. Dasar-dasar Evaluasi Pendidikan. Jakata: Bumi Aksara.

Dantes, Nyoman. 2012: Metode Penelitian. Yogyakarta: Andi Offset.

Kosasih. 2014. Strategi Belajar dan Pembelajaran Implementasi Kurikulum 2013. Bandung: Yrama Widya.

Munir. 2012. Multimedia Konsep \& Aplikasi dalam Pendidikan. Bandung: Alfabeta.

Putra, I Ketut Dedi Agung Susanto. 2017. Pengaruh Model Pembelajaran Inquiry Terbimbing Berbantuan Peta Pikiran Terhadap Hasil Belajar IPA Kelas V SDI. Universitas Pendidikan Ganesha: Vol 5 No: 2.

Rasana, I Dewa Putu Raka. 2009. Model-model Pembelajaran. Sinagaraja: Universitas Pendidikan Ganesha.

Samatowa, Usman. 2010. Pembelajaran IPA di Sekolah Dasar. Jakarta: PT. Indeks.

Sani, Ridwan Abdullah. 2015. Pembelajaran Saintifik Untuk Implementasi Kurikulum 2013. Jakarta: Bumi Aksara.

Setyosari, H. Punaji. 2015. Metode Penelitian Pendidikan dan Pengembangan. Jakarta: Kencana. 
Sudijono, Anas. 2015. Pengantar Evaluasi Pendidikan. Jakarta: Rajawali Pers.

Sugiyono. 2017. Metode Penelitian Kuantitatif, Kualitatif, dan R\&D. Bandung: Alfabeta.

Sumantri, Mohamad Syarif. 2015. Strategi Pembelajaran. Jakarta: PT. Rajagrafindo Persada.

Suryanta, I Made. 2014. Pengaruh Model Pembelajaran Scrambel Berbantuan Media Gambar Animasi Terhadap Hasil Belajar IPA Siswa Kelas V SD Gugus Yos Sudarso Denpasar. Universitas Pendidikan Ganesha: Vol 2 No: 1.

Susanto, Ahmad. 2013.Teori Belajar dan Pembelajaran di Sekolah Dasar. Jakarta: Prenadamedia Grup.

Tabany, Trianto Ibnu Badar Al. 2014. Mendesain Model Pembelajaran Inovatif, Progresif, dan Kontekstual. Jakarta: Prenamedia Group.

Wisudawati, Asih Widi dan Eka Sulistyowati. 2014. Metodelogi Pembelajaran IPA. Jakarta: Bumi Aksara. 